\title{
Teachers' Creativity in Using Attention Grabber in EFL Class
}

\author{
Yuni Arifadah \\ Faculty of Education \\ UIN Sunan Ampel Surabaya \\ yuniarrifadah@uinsby.ac.id \\ Tri Rohmat Sholehuddin \\ Faculty of Education \\ UIN Sunan Ampel Surabaya \\ trirohmat5@gmail.com
}

\author{
Robet Rio \\ MTsN 3 Mojokerto \\ Mojokerto \\ robetrio99@gmail.com \\ Ayuningtyas Febri Paramita \\ Faculty of Education \\ UIN Sunan Ampel Surabaya \\ ayuningtyas26.at@gmail.com
}

\author{
Nadiyah Mafazatin Nailiyah \\ Faculty of Education \\ UIN Sunan Ampel Surabaya \\ nadiyahnailiyah15@gmail.com
}

\begin{abstract}
This study aims at investigating the teachers' creativity in using attention grabber in the EFL classroom and evaluating the challenges while applying the attention grabber in the EFL classroom. Students have different ability in concentrating during the teaching and learning the classroom. To grab the students' attention, the teachers use various attention grabbers, which are beneficial. The respondents of this research were 12 students from 6 different classes in MTsN 3 Mojokerto. The researcher is interviewing the respondents and doing the classroom observation to investigate and evaluate the problems. The observation and interview were recorded using video and voice recorder, respectively. The finding shows that the teacher uses four kinds of attention grabbers. They are sounding, hissing, shouting, and clapping. The students showed the positive respond of applying attention grabber. The study also found that there are some challenges in using attention grabber in the EFL classroom. The first challenges in using attention grabber in the classroom, it is about some students who do not respond to the attention grabber because they are too busy with their friends and their own business. Some students also stated that they are not interested in the English lesson.
\end{abstract}

Keywords: teaching creativity, attention grabber, challenges, students' attention

\section{INTRODUCTION}

It is a typical teachers' experience that not all students can pay attention to them while lecturing. One of the factors is that the students may have different cognitive practices for concentrating on the learning process. Some students can concentrate easily while some others cannot do the same. Benjamin stated that the students would lose their attention to the teacher after 10 minutes. Teachers should refresh the students' brain to focus until they are ready to listen and pay attention again. This is one of challenging tasks in managing the classroom. It is the consideration of the teacher in managing the classroom. Classroom management still relates to the strategies that the teacher use in the class. Strategies in teaching and the students' attention are related to each other. If the sitting arrangement and the teaching activities are interesting, the students can be more focus and keep their attention and never miss the information from the teacher. If the sitting arrangement and the activities cannot attract the students' attention, the students will do something which drifts from the teaching and learning process.

To avoid the attention problem of the students in a class, the teacher needs to apply the strategy to grab the students' attention. Attention is the requirement of transfer materials. It will be unnecessary if the teacher explains while the students busy doing their own business unrelated to the lesson. The effect of this problem is the students cannot understand the materials and they ask personally to the teacher. Sometimes, it will be beneficial for the students personally, but it is not for all the learners and also the teacher. Thus, attention grabber is needed to be applied in the classroom when the teacher feels that the atmosphere of the students is not conducive.

The success of applying attention grabber with various activities was proved by the finding of Jeff Cain, EdD, Esther P. Black, Phd, and jurgen Rohr, Phd who found that specific ARS is the one of successful strategies for getting the students attention during lectures. Besides, there is a fun way 
with Craft who argues that teachers' personal creativity that is shown in their everyday practices is a major element of creative teaching. Teacher's creativity includesanalyzingstudents' creative strengths and promoting their creativity. This is unlikely will happen unless the teacher is willing to teach creativity. Only with teachers' willingness and dedication, teaching creatively will enable students' personal development in some respects; spiritual, moral, social and culture (Eaude, 2009).

\section{Students'Attention}

Taylor and Parson define attention as 'student's willingness, need, want and coercion to participate, and be successful in the learning process'. Students' attention refers to students' uniqueness of focus, efforts and mental state during learning process. Students' paying attention can be seen when they are interested in the subject and excitedin doing the activities. Taylor and Parson further offer some indicators of students' attention:

"the attention of students to the teacher's explanation, the cooperation in the group, the ability of students to express their opinions in expert groups, the ability of students to express opinions in a group native, and provide opportunities argues to friends in the group, listening carefully when a friend argues, provides a brilliant idea., make a plan and division of labor which ripe, the decision is based on considerations of other members, exploiting the potential of the group members, and mutual help and resolve problems". technique of teaching instruction employed by the teachers to assist students to learn and to use their knowledge to reach the desired course goals. Teaching strategies allows teachers to analyze variety teaching strategies and eventually create and improve the appropriate strategy which best suitable with students needs. McIntosh, Herman, Sanford, McGraw, \& Florence offers four strategies that teachers can adopt to grab students focus during the learning process; they are hissing, sounding, singing and clapping. However, based on McIntosh (2004) there is one strategy which not found by the researcher in this research that is singing, and there is also one strategy which not mentioned by him that is staring.

\section{B. Teacher's Creativity}

The notion of creative teaching and teaching for creativity has been discussed widely in the field of teaching and learning. It involves four aspects: relevance, ownership, control and innovation (Cremin, 2009). Cremin argues that creative teaching "engage teachers to make learning more interesting and effective and using imaginative approaches in the classroom". It means that creative teaching involves teachers' character and their creativity, and its manifestation in daily activities. It is line

\section{Attention Grabber}

One of the major difficulties of teachers in classroom management is having students to pay attention.The learning process will be ineffective and not conducive if students do not show attention to the teacher. it is the teacher's responsibility to use attention grabber to attract students' attention. McDowell has employed attention-grabbing calls such as shouting the phrase "class..class". The calls trigger student respond with both verbal and physic responses such as shouting '"prok..prokk sshhtttt". In getting students attention, it can be applied in a crowded class. When most of the students do not pay attention, teacher should not be continuing to explain the material. The teacher should refresh their brain to focus until they are ready to listen and pay attention. The implementation of attention grabber in class might be the best way to make the students focus.

McDowell, further, offers 20 simple ideas that teacher can adapt to gain their students' attention in the classroom. They are:

1.Teacher says, "One, Two" - Students' response,
"Eyes on you." 
change of sense-organ. Perception divided into positive perception and negative perception. 1) Positive perception means showing the self-confidence and power to face crises. 2) Negative perception means disposed of their ambitions, trying to stand on their self-worth.

4.Teacher says, "If you can hear me clap once, if you hear me clap twice."

5.Teacher says, "Hear Ye Hear ye" - Students' response, "All eyes on the queen."

6.Teacher says, "Give me five" - Students respond by raising their hand.

7.Teacher says, Peanut butter" - Students say "Jelly."

8.Teacher says, "Tomato" - Students say "Tomahto."

9.Teacher says, "Ready to Rock?" - Students response, "Ready to Roll."

10. Teacher says, "Hey" - Students respond with "Ho."

11. Teacher says, "Macaroni" - Students respond with "Cheese."

12. Teacher says, "Marco" - Students respond, "Polo."

13. Teacher says, "One fish, Two Fish" - Students response, "Red Fish, Blue Fish."

14. Teacher says, "Silent Guitar" - Students respond by playing air guitar.

15. Teacher says, "Silent Wiggles" - Students respond by dancing around.

16. Teacher says, "Hocus, Pocus" - Students response is "Everybody focus."

17. Teacher says, "Chocolate" - Students response, "Cake."

18. Teacher says, "All set" - Students say, "You bet."

19. Teacher says, "Hands on top" - Students say, "That means stop!"

20. Teacher says, "Chica Chica" - Students say, "Boom Boom."

\section{E. Perception}

Perception is a corporation, the description, and identification of the impression in order to figure a psychological illustration of someone. Every person has their point of view on something. It same as what Aristotle stated that perception object would be impacted to the

\section{F. $\quad$ The importance of students ' perception}

With knowing the perception of the students about the teacher creativity in applying attention grabber in the classroom, the teacher can evaluate their teaching. Chen argues that knowing students' perception is important to evaluate the effectiveness of using attention grabber in the classroom process. According to Petegem's study Students' perception is also really significance to measure the result of students' learning. It is not only for knowing the perception but it is also for the development of teaching purposes.

\section{METHOD}

The study used descriptive qualitative method. Qualitative research usually employed for giving a resourceful description, triangulation, member checking, external audits, and peer review. This method is commonly used to conduct researches in various disciplines, such as education, language, social science, and psychology. Naturalness is the characteristic of qualitative research method. The qualitative data can be collected by observing the classroom, recording the interview, collecting various type of text as sources, and also images. According to the objective of this research, this research needs to be as natural as possible to get the valid data and need varieties of data to reach the result.

In this case, this qualitative research analyzes the teacher creativity in using attention grabber in the EFL classroom. It specifically aims to describe the students' response to the attention grabber which had applied in teaching and learning process. The research was conducted on MTsN 3 Mojokerto. There are six classes that we took for this research. It takes two students each class to be interviewed personally as participants of this research.

\section{FINDINGS AND DISCUSSION}

\section{A. Teachers' Creativity in Using Attention Grabber During Teavhing and Learning Process}

According to the classroom observation and interviewing the students, there are three kinds of attention grabber that the teachers of MTsN 3 Mojokerto usually use in the teaching and learning process. The first strategy that the teacher uses to grab the students' attention is sounding. In this case, the teachers are usually knotting things around them. For example, the teacher is knotting the table or the whiteboard using a marker or pen. The teacher will tap the marker once more time to make a louder noise if the first 
refresh their brain. Because Benjamin stated that the students would lose their attention to the teacher after 10 minutes. So, the teachers need to apply attention grabber to make them concentration again and follow the activities well.

In addition, almost of the interviewees say that all of the teachers should use the attention grabber in the teaching and learning process because they think it is important. They are aware that they were losing their concentration during the materials. It is one of the reasons to use the attention grabber. Moreover, some of the interviewees say report that they usually annoyed with their friends that talking with their friends or make an annoying sound. The students said that attention grabber could help them to solve that problem. The choice of attention-grabber also shows the teachers characteristic since it is based on teachers' preferences.

Although attention grabber can grab students attention, not all of the attention grabber can be applied in the class by the teacher. Shouting and Sounding are the strategies that the students do not prefer. They said when the teachers are shouting, they feel scared and not comfortable to do the activities in the class. It is also demotivatating as students appear to be insecure about contributing to the class discussion.

The attention grabber that students like most is clapping. The students argue that clapping is the most interesting attention grabber. It was fun and really refreshed their brain. According to the classes' observation, some of the classes make innovation with the strategy to grab the students' attention using clapping. So, when the teacher say " Class.. class.." then the students respond by saying "(clapping twice) teeeeeeeet". This is a fun way to grab their attention. grabbers. Nevertheless, the teachers believe that clapping is the one of applicable and straightforward strategy to grab the students' attention. The uses of this attention-grabber are not different from the attention grabber that used by the other teachers. It is used to make the class conducive and to refresh the concentration of the students. It is also can attract the students' focus and interest in our class. Before applying in the class, the teacher needs to tell the students about how to respond. The teacher said that when the teacher says "Class.. class.." and then the students have to respond "(clapping twice) Ssssssssst.....". This is one of various attention grabber using clapping. It works when it applies in the classroom. The students stop talking and playing and back to be concentration to the teacher and the material.

\section{B. The response of the students about the attention grabber}

In observing and interviewing the students from various classes, they show the positive responses of applying attention grabber in the class. They can response the attention grabber after the teacher gives the explanation about it in the beginning of the class. There are eight students that the researchers taken to be interviewed and all of them state that attention grabber is the effective way to

\section{The challenges of applying attention grabber}

Applying attention grabber in the class is not thoroughly attracting the students' attention. Some of them did not respond to the attention grabber for some reasons. The first reason is they are talking with their friends and cannot hear the instruction. It can be the initiative of the student, or their friend urged him or her to keep talking. The second reason is they did the other materials' homework during English class. Although the teacher has reminded them, they still do their homework.

Not all of the students are interested in English material. Some of them say that "English is too difficult", "English is hard", "We are Indonesian miss, we do not need to learn English", and other reasons. This may also be the reason why the students do not focus during the classroom activities.

\section{CONCLUSION}

The study aims at finding the answer to two questions. The first is about the teachers' creativity in using attention grabber in EFL classroom. The second is about the challenges during applying attention grabber in 
attention, and feedback, American journal of Pharmaceutical education $73(2), 21)$

Mojokerto.

It is general knowledge that students have different learning styles and ability, including the ability to focus on the lesson during classroom activities. The teacher solves that problem using attention grabber. From the classroom observing and students' interviewing, there are four strategies which are used by the teacher to grab the students' attention, or we can call it as an attentiongrabber. Those are Sounding, Hissing, Shouting, and clapping. The research found that clapping is the one of attention grabber that the students like most because it is interesting and can make them concentrate again.

From the result of the research, some challenges were found. The first was the students' response to applying attention grabber. Some of the students did not respond to the attention grabber because they keep talking with their friends and they did their own business. Moreover, the reason why the students' unwillingness to respond to the attention grabber is they are not interested in learning English lesson.

\section{REFERENCES}

[1] Benjamin, L.T., Jr. , 2002, The teaching of pshycology : essay in honor Mahwah, NJ: Lawrence Erlbaum Associates, Inc.

[2] Eka Purwanti,Kisman Salija, dan Syarifudding Dollah, Teachers' strategies in getting students' attention during transition in EFL Classroom (A case study on English Teacher in Junior High School.

[3] Tamara van Gog, Halszka jarodzka, katharina scheiter, peter gerjets, and Fred Paas, 2009. Attention guidance during example study via the model'd eye movements. Elseiver, 25.

[4] Jeff Cain, EdD, Esther P. Black, Phd, and jurgen Rohr, Phd; 2009, An Audience Response System Strategy to improve students motivation,
[5] Erik Rosegard and Jackson Wilson; 2018, Capturing students' attention: An empirical study, Journal of the scholarship of teaching and learning, vol 13, no.5.

[6] Maxwell J.A. , 1996, Qualitative research design: An interactive approach. Thousand Oaks.

[7] Nassaji, H. , 2015, Qualitative and descriptive research: Data type versus data analysis. Language teaching research, 21-27

[8] Dornyei, Research methods in applied linguistic. 2007.

[9] Khoirul anam, Ahmad Munir, and Syaiful Anam, 2019, Teachers' perception about authentic materials and their implementation in the classroom. IJET, vol. 8

[10] Daniel L. Schater, gilberts, wegner, 2009

[11] simo knuutilla, 2008, theories of perception in Medieval and Early Moslem Philosophy, ,1.

[12] Yining Chen and Leon B Hoshower, 2003, student evaluation of teaching effectiveness: An Assessment of student Perception and motivation, vol 28, 1.

[13] Scoot Mc Dowell. 2019. 3 Attention Grabbers for Effective Classroom Management!

[14] Cremin, T. 2009, Creative Teachers and Creative Teaching. In Anthony Wilson (ed), Creativity in Primary Education, 2nd ed. (pp. 36-46), Exeter: Learning Matters Ltd.

[15] Craft, A. 2009, Changes in the Landscape for Creativity in Education. In Anthony Wilson (ed), Creativity in Primary Education, 2nd ed. (pp.521), Exeter: Learning Matters Ltd.

[16] Hong, E., Hartzell, S.A. \& Greene, M.T. 2009, Fostering Creativity in the Classroom: Effects of Teachers' Epistemological Beliefs, Motivation, and Goal Orientation. Journal of Creative Behavior, 43(3), 192-208.

[17] Taylor, Leah \& Parsons, Jim. 2011, Improving Student Engagement. Cie.edu, Volume 14, Number 1. Retrieved from http://cie.asu.edu/

[18] Santrock, John. W. 2011, Psikologi Pendidikan. Edisi Kedua. Jakarta: Salemba Humanika.

[19] McIntosh, K., Herman, K., \& Sanford, A. Teaching Transition Techniques for Promoting Success Between Lessons. Library teaching, Vol.37 No.1 Teaching Exceptional Children. pdxscholar. 